УДК: 330.131 .3

Н. В. Шакун, к. фрілос. н., доцент

\title{
ДО ПИТАННЯ КОНЦЕПТУАЛІЗАЦІЇ ПОНЯТТЯ КУЛЬТУРНИХ ТА КРЕАТИВНИХ ІНДУСТРІЙ
}

Актуальність теми дослідження. В контексті руху України до Європейського союзу варто враховувати передовий західний досвід розвитку культурного сектору, переосмислити його з урахуванням вітчизняної етноментальної специфіки.

Постановка проблеми. Вивчення процесів суспільної трансформації в сучасній Україні передбачає розробку $і$ аналіз нових концептів, спроможних їх відтворити і здатних всебічно теоретично репрезентувати. До таких належить концепт культурних $i$ креативних індустрій.

Аналіз останніх досліджень. Тему культуротворчого потенціалу креативних індустрій розробляють такі вчені, як Є. Богатирьова О. Лазарєва, С. Олійник, І. Петрова, В. Солодовник та ін.

Виділення недосліджених частин загальної проблеми. Першочергового дослідження потребує поняття, передумови виникнення та перспективи становлення креативних індустрій.

Постановка завдання. Метою публікації $\epsilon$ аналіз походження та семантичних нашарувань поняття «культура», «творчість», «креативність» та похідних від них термінів "культурні індустрії» $і$ «креативні індустрії»», які сьогодні є часто вживаними у наукових студіях.

Виклад основного матеріалу. Вже на початковому етапі дослідження терміну «креативні індустрії» виявляється значні розбіжності у його тлумаченні. Велика увага науковців до проблематики креативних індустрій, широкий спектр підходів і досліджуваних явищ породжують багатозначність цього відносно нового в українському науковому дискурсі поняття. Аналіз змістовного навантаження терміну «креативні індустрії» та особливостей його інтерпретації зарубіжною і вітчизняною науковою думкою, дозволяє констатувати, що спільною у вищезгаданих дослідженнях стає проблематика взаємодії культури і економіки.

Висновки. Обгрунтовано, що комплексне дослідження френомену креативних індустрій можливе лише за умови урахування множинності підходів до інтерпретації культури у західноєвропейській фрілософрії та особливостей тлумачення культури в контексті вітчизняної світоглядної традиції.

Ключові слова: культура; творчість; креативність; культурні індустрі; креативні індустрії.

N. V. Shakun, Candidate of Philosophical Sciences, Associate Professor

\section{CONCEPTUALIZATION OF THE CONCEPTS OF "CULTURE" AND "CREATIVE INDUSTRIES"}

Urgency of the research. In the context of the Ukraine's integration into the European Union, it is necessary to take into account the advanced western experience in the development of the cultural sector, to rethink it taking into account our native, ethno-mental specifics.

Target setting. The study of the processes of social transformation in modern Ukraine involves the development and analysis of new concepts that can reproduce them and comprehensively present them theoretically. They include the concept of cultural and creative industries.

Actual scientific researches and issues analysis. The theme of the culture-creating potential of creative industries is developed by such scientists as Ye. Bohatyrova, O. Lazarieva, S. Oliinyk, I. Petrova, V. Solodovnyk et al.

Uninvestigated parts of general matters defining. Consequently, the priority for the research are the concept, prerequisites for the emergence and prospects of the formation of creative industries.

The research objective. The purpose of the publication is the study of the role of creative (cultural) industries with the analysis of the origin and semantic layers of the concept "culture", "creativeness", 
"creativity" and derivatives of the terms "cultural industries" and "creative industries", which today are often used in scientific studios.

The statement of basic materials. There are significant differences in the interpretation of the term "creative industries" even at the initial stage of its study. The great attention of scientists to the problems of the creative economy and creative industries, a wide range of approaches and the phenomena under investigation generate the ambiguity of this concept, which is relatively new in the Ukrainian scientific discourse. An analysis of the semantic load of the term "creative industry" and the peculiarities of its interpretation by foreign and domestic scientific thought allows us to state that the problem of interaction between culture and economics at the present stage of social transformation becomes common in the aforementioned studies.

Conclusions. A comprehensive study of the phenomenon of creative industries is possible only if we take into account the multiplicity of approaches to the interpretation of culture in Western European philosophy and the peculiarities of the interpretation of culture in the context of domestic worldview tradition.

Keywords: culture; creativity; creativeness; cultural industries; creative industries.

DOI: 10.25140/2412-1185-2019-2(14)-91-99

Актуальність теми дослідження. Під впливом сучасних тенденцій глобалізації та інтернаціоналізації зазнає трансформації духовна сфера суспільного життя, поглиблюється культурна диференціація та регіоналізація. В інформаційному суспільстві культура виконує роль транслятора суспільних надбань, постає процесом творення нових знань, досвіду, цінностей. Це позначається на уявленні про характер етнокультурних взаємин, потенціал культури як вираження нових тенденцій суспільної динаміки, значення впливу культури на розвиток суспільства.

До загальносвітових тенденцій варто додати й ту, що на пострадянському просторі і нині продовжуємо спостерігати життєздатність утворень суперечливої радянської культури, яка орієнтувалась на ствердження «загальнолюдського» через нівелювання «національного» $\mathrm{i}$ призвела до неоднозначного ставлення українців до власних культурних надбань. Як влучно зауважують вітчизняні дослідники, «сімдесятирічна «радянська доба» розвитку української культури $€$ узагальнюючим акордом історичної трагедії народу i одночасно тріумфу життєздатності нації, яка знайшла в собі сили вистояти, зберегти і примножити культурні надбання, вирватись з обіймів тоталітаризму і зробити крок у майбутнє» $[1$, с. 47].

Водночас, постіндустріальне суспільство характеризується появою нового феномену суспільного буття - креативних індустрій, як специфічних соціокультурних практик, що пов'язані як з виробництвом масової культури, так і з локальними креативними ініціативами. Критичний аналіз їх появи, вивчення практики їх використання у наукових розвідках, на наш погляд, сприятиме визначенню перспектив їх розвитку для подальшої еволюції України.

Постановка проблеми. Ефективне управління культурними проектами та розвиток культурних і креативних індустрій в сучасних умовах неможливі без урахування основних західноєвропейських та вітчизняних підходів до усвідомлення природи культури та особливостей їх трансформації на сучасному етапі суспільних перетворень. Отож, для дослідження потенціалу культури в умовах глобалізації та складних процесів національного культуротворення в українському суспільстві, слід звернутися до аналізу концепту «культура», «креативність», «Культурні індустрії», «креативні індустрії» та виокремити основні підходи до їх тлумачення.

Аналіз останніх досліджень та публікацій. Довкола проблеми сутності та характерних рис культури зосередились пошуки таких західноєвропейських філософів, як В. Дільтей, Г. Зіммель, Г. Ріккерт, А. Тойнбі, Й. Хейзінга, В. Франкл, Е. Фромм, А. Швейцер та ін. Плідні філософрські спроби аналізу природи культури здійснили українські мислителі Г. Сковорода, Т. Прокопович, П. Юркевич, М. Драгоманов, І. Франко, В. Липинський, та ін. В працях таких сучасних вітчизняних вчених, як В. Андрущенко, Є. Бистрицький, І. Бойченко, П. Гнатенко, Л. Губерський, В. Литвинов, М. Михальченко, В. Нічик, М. Попович, В. Шевченко та ін. репрезентовані основні новітні парадигми осмислення процесу культуротворення. 
Концепція креативних індустрій є відносно новою у західноєвропейському гуманітарному дискурсі, оскільки сорормувалась в 70-ті рр. минулого століття. Саме в цей період на Заході склалися технологічні та інформаційно-комунікативні передумови формування креативних індустрій: індустріалізація, урбанізація, скорочення традиційних та поява нових форм зайнятості на ринку праці. Підґрунтя концепції креативних індустрій склали ідеї переоцінки впливу культури на розвиток суспільства, які у підсумку породили відмінні концептуальні напрямки дослідження.

Першочергово до аналізу суспільного потенціалу креативних індустрій звернулись фрілософии і соціологи, однак реальні шляхи пошуку трансформації суспільства засобами культури обґрунтували економісти. Так, в працях Т. Адорно, З. Баумана, Д. Белла та ін. мислителів креативні індустрії розглядались як тип соціально-культурних практик, що сформувались внаслідок становлення постіндустріального суспільства.

Натомість фундатори концепції «креативної економіки» Дж. Хокінс, П. Луїджі Сакко та ін. акцентували увагу на креативних індустріях як секторі економіки, що створює додаткову вартість і робочі місця шляхом виробництва і експлуатації інтелектуальної власності. 3 позицій економічного підходу аналіз креативних індустрій нині здійснюють такі сучасні вітчизняні науковці, як С. Киризюк, Х.Лошковська, М. Проскуріна, А. Холодницька, О. Чуль та ін.

Тему культуротворчого потенціалу креативних індустрій розробляють такі сучасні вітчизняні науковці, як І. Петрова, С. Олійник, В. Солодовник, а також російські вчені Є. Богатирьова, $€$ Є. Зєлєнцова, О. Лазарєва та ін.

Виділення недосліджених раніше частин загальної проблеми. Попри зростаючий інтерес вчених та появу значної кількості зарубіжних і вітчизняних міждисциплінарних досліджень, теоретико-методологічні засади дослідження культурних та креативних індустрій, вочевидь, є маловивченими та потребують дослідницької уваги. Важливим нам видається аналіз широкого діапазону точок зору на розуміння культури, творчості, креативності та такого феномену сучасності, як креативні індустрії. Тим більше, що значна увага науковців до проблематики креативної економіки, креативних індустрій, широкий спектр підходів і досліджуваних явищ породжують багатозначність цього відносно нового в українському науковому дискурсі поняття. У зв'язку з тим, що у вітчизняному науковому дискурсі досі відсутнє одностайність у тлумаченні креативних індустрій, визначення концептуальних підходів до їх сутності сприятиме як теоретичному осмисленню цього феномену, так і дослідженню його практичного впливу на всі сфери суспільного буття.

Постановка завдання. Проаналізувати теоретико-методологічні підстави дослідження культури та культурних і креативних індустрій. Досягнення дослідницької мети передбачає реалізацію таких основних завдань: по-перше, проаналізувати походження та семантичні нашарування понять «культура», «творчість», «креативність» та похідних від них термінів «культурні індустрії» і «креативні індустрії»», які сьогодні є часто вживаними у наукових студіях; по-друге, дослідити сутність основних теоретико-методологічних підходів до їх тлумачення; потретє, визначити специфіку тлумачення культури та креативних індустрій в контексті української світоглядної традиції.

Виклад основного матеріалу. В умовах наростання в Україні тенденцій «культурної децентралізації, зокрема через повернення значущості традиційним центрам української культури і створення нових» [2, с. 125], стає зрозумілим, що культура є не просто «надбудовою» над економікою, а стає основою економічного зростання міста, регіону, країни.

Поняття культура (від лат. culture - «обробіток») багатозначне і набуває різних смислових відтінків в залежності від підходу, в контексті якого вживається. Аналіз численних пояснювальних схем та світоглядно-методологічних уявлень, представлених у зарубіжній та вітчизняній гуманітарній думці, дозволяє виокремити декілька основних підходів до усвідомлення природи культури: аксіологічний, діяльнісний, знаково-семантичний, психологічний, ігровий, матеріалістичний, стихійно-повсякденний і філософський (Табл. 1).

Розглянемо вказані підходи докладніше.

Аксіологічний підхід до осягнення сутності культури представлений у роботах Е. Фрома, В. Франкла, А. Швейцера, Г. Ріккерта, В. Дільтея та ін. В його контексті культура розглядається як сукупність матеріальних і духовних цінностей, створених людиною в процесі суспільно-історичної діяльності. Цінності виконують роль своєрідних дороговказів як у суспільному поступі, так і в особистісній та професійній реалізації індивіда. В умовах різних життєвих обставин, цінності 
зазнають трансформації, обумовлюючи тим самим переміну не лише світогляду особистості, але й характеру суспільної динаміки (П. Сорокін). Так, скажімо на сучасному етапі трансформації українського суспільства спостерігаємо протистояння двох культурних парадигм: перша орієнтовна на цінності «радянського» світогляду (зрівнялівка, колективізм, конформізм та ін.), а в основі другої перебувають цінності відкритого суспільства (свобода, активізм, самореалізація, соціальна довіра, соціальна відповідальність тощо).

Таблиця 1

Теоретико-методологічні підходи до тлумачення культури

\begin{tabular}{|c|c|c|}
\hline Назва підходу & Сутність & Фундатори \\
\hline Аксіологічний & $\begin{array}{l}\text { Культура досліджується крізь призму матеріальних і духовних } \\
\text { цінностей, створених людиною в процесі суспільно-історичної } \\
\text { діяльності }\end{array}$ & $\begin{array}{l}\text { Е. Фромм, } \\
\text { А. Швейцер, } \\
\text { Г. Ріккерт, }\end{array}$ \\
\hline $\begin{array}{l}\text { Символіко- } \\
\text { семантичний }\end{array}$ & $\begin{array}{l}\text { Акцентує знакову природу культури і тлумачить її як світ смислів і } \\
\text { значень }\end{array}$ & $\begin{array}{l}\text { Е. Кассірер, } \\
\text { Ю. Лотман }\end{array}$ \\
\hline Діяльнісний & $\begin{array}{l}\text { Культура трактується як специффічно людський спосіб діяльності, } \\
\text { продукт спільної праці, результат творчої діяльності людей }\end{array}$ & $\begin{array}{l}\text { М. Каган } \\
\text { К. Бюхер }\end{array}$ \\
\hline Психологічний & $\begin{array}{l}\text { Культура - це сублімація, тобто заміна сексуально-біологічних } \\
\text { інстинктів створенням різних предметів і творів мистецтва, які } \\
\text { символізують бажаний, але недоступний об'єкт потягу }\end{array}$ & 3. Фройд \\
\hline Матеріалістичний & $\begin{array}{l}\text { Культура - це штучний, соціальний світ; } \\
\text { все, що створене людиною, на відміну всього того, що створене } \\
\text { природою }\end{array}$ & Г. Плєханов \\
\hline Ігровий & Культура виникла як гра в результаті еволюції людини & Й. Гейзінга \\
\hline Повсякденний & $\begin{array}{l}\text { Культура ототожнюється } 3 \text { мистецтвом, музикою, театром, } \\
\text { літературою, освітою і вихованням }\end{array}$ & \\
\hline $\begin{array}{l}\text { Філософсько- } \\
\text { антропологічний }\end{array}$ & $\begin{array}{l}\text { Культура розглядається як результат і спосіб зв'язку людини з } \\
\text { дійсністю; перенесення цінностей сучасності в буття людини; } \\
\text { утвердження людини та прояв її сутнісних сил; підкреслюється } \\
\text { принципова антропоцентричність світу культури }\end{array}$ & $\begin{array}{l}\text { В. Шинкарук, } \\
\text { А. Яценко, } \\
\text { С. Кримський }\end{array}$ \\
\hline
\end{tabular}

Джерело: сформовано автором

В контексті діяльнісного підходу (М. Каган) культура постає специфічно людським способом діяльності, тобто результатом пошуково-перетворювальної діяльності людей, яка спрямована на вдосконалення вже існуючого, а також пошук і відкриття нового. Таким чином, культура тісно пов'язана з творчістю - діяльністю, завдяки якій створюється щось унікальне, продукуються нові ідеї та натхненно втілюються у життя. Німецький вчений К. Бюхер висунув трудову теорію культури, вважаючи, що вона народжується спільною працею.

Знаково-семантичний підхід (Е. Кассірер, Ю. Лотман, К. Леві-Строс) акцентує знакову природу культури і тлумачить її як світ смислів і значень. Так, Ю. Лотман культурою називає «сукупність всієї не спадкової інформації, способів ії̈ організації і зберігання» [3, с. 422]. В центр уваги представників цього підходу виходить проблема соціокультурного коду-тексту, причому під останнім розуміється і художній твір, і звичай, і будь-який витвір культури.

Психологічний підхід розглядає культуру як сублімацію, тобто заміну сексуально-біологічних інстинктів створення різних предметів і творів мистецтва, які символізують бажаний, але недоступний об'єкт потягу. Така інтерпретація культури наявна у творах австрійського психіатра 3. Фройда, на думку якого, культура - створення житла, одягу, мистецтв - врятувала людство від розчинення у тваринному світі.

3 позицій матеріалістичного підходу (Г. Плєханов, К. Маркс) культура виявляє свою штучну природу. Тобто культура - це штучний, соціальний світ; все, що створене людиною, на відміну всього того, що створене природою таке розуміння було тривалий час поширене на пострадянському просторі, в умовах панування марксистсько-ленінської фрілософії і почало здавати свої позиції в наш час. Марксисти вбачали в культурі ідеологічну надбудову над економічним життям суспільства, вважаючи, що в культурі у прихованому вигляді постійно кипить боротьба інтересів різних класових угрупувань. Натомість сьогодні стає очевидним

Ігровий підхід культура виникла як гра в результаті еволюції людини. Так, Й. Й.Гейзінга у своїй роботі «Homo Ludens» доводить, що будь-який витвір духу, що стає традицією, є грою. Гра 
орієнтується на сфреру духовності, вона «передається далі, стає традицією» [4, с. 16-17].

Варто підкреслити, що на рівні повсякденної свідомості, культура ототожнюється 3 мистецтвом, музикою, театром, літературою, освітою і вихованням.

Філософрсько-антропологічний підхід до осмислення культури, який сформувався завдяки зусиллям українських мислителів минулих століть і розроблявся сучасними вітчизняними філософрами (В. Шинкарук, А. Яценко, С. Кримський, В. Шевченко та ін.), таким чином, підкреслює принципову антропоцентричність світу культури. В його контексті культура розглядається як результат і спосіб зв'язку людини 3 дійсністю, перенесення цінностей сучасності в буття людини, утвердження людини та прояв ії сутнісних сил.

Ураховуючи множинність підходів до інтерпретації культури у західноєвропейській філософоській думці, звернемо увагу на його тлумачення в українській світоглядній традиції. Давньоукраїнським аналогом латинського поняття «культура» було слово «художества». Це означає, що культурою українські мислителі називали дещо створене, відмінне від оригіналу, дійсності. Скажімо, «Т. Прокопович у свій час висловлював загальну точку зору, властиву українській філософії, коли говорив, що твори культури в цілому штучні, «якісь неживі» і, як вироби серед речей, здатні лише руйнуватися і безслідно зникати» [5, с. 422]. Культура, вважалось, антропомірна, адже саме людина наділена здібністю до «художеств», а саме культуротворчими здібностями.

Під творчістю, отже, розуміємо таку діяльність, завдяки якій створюється щось нове, унікальне. У зв'язку з цим уточнення потребує термін «креативність», який у Великому тлумачному словнику української мови розглядається як синонім до слова «творчість» [6]. Англійське слово «креативність» (creativity) (від лат. creation - створення, породження) здебільшого вживається для позначення специфічної властивості інтелекту, або необхідної передумови самореалізації людини, чи потреби в пошуково-перетворювальній діяльності тощо. Тому «креативність» людини означає фрормулювання нею нових ідей, інноваційних підходів та впровадження їх практику $з$ метою отримання оригінального продукту - матеріального і/чи духовного.

В сучасній гуманітарній думці креативність розглядається як характеристика особистості, зокрема ії̈ здатність проявляти оригінальність, продуктивність, гнучкість при виборі способів вирішення проблем, бажання ризикувати, надання переваги невизначеності над одноманітною впорядкованістю. Здатність креативно мислити, як правило, пов'язується з множинністю шляхів вирішення проблеми, що дозволяє отримати оригінальні, нестандартні, неочікувані результати і розв'язки проблеми.

Таким чином, «творчістю» ми називаємо людську діяльність, завдяки якій створюється щось нове, унікальне, а англомовним терміном «креативність» позначаємо характеристику особистості, яка обумовлює іï спроможність до творчості, здатність оригінально мислити (вдаватися до мисленнєвих експериментів), продукувати нові ідеї та натхненно втілювати їх у життя.

Водночас, підкреслюючи наявність широкого діапазону точок зору на розуміння творчості i креативності, сучасні науковці відстоюють думку за якою «творчий процес ґрунтується на натхненні автора, його здібностях, традиціях, а креативний процес має у своїй основі прагматичний елемент, тобто початкове розуміння, навіщо потрібно щось створювати» $[7$, с. 36]. Це означає, що креативність $€$ не лише характеристикою особистості, а й соціальним процесом в результаті якого група людей створює щось нове, що слугує рушійною силою розвитку суспільства.

У світлі вищезазначеного досить неоднозначним виявляється зміст понять «культурні індустрії» та «креативні індустрії». Термін індустрія (від лат. industria - діяльність) позначає промисловість, промисел і пов'язується, не з новизною чи унікальністю, а насамперед, із серійністю виробництва. У зв'язку з цим культурна індустрія - це, те, що має стосунок не стільки до творчості, скільки до серійного виробництва, тиражування культурного продукту. На цьому наполягали представники Франкфуртської школи соціології, які ввели термін «культурні індустрії» в науковий обіг, збуривши дискусію про масову культуру та наслідки демократизації доступу до культурних надбань і комерціалізації розваг.

Вже на початковому етапі дослідження терміну «креативні індустрії» виявляється значні розбіжності у його тлумаченні. Велика увага науковців до проблематики креативної економіки, креативних індустрій, широкий спектр підходів і досліджуваних явищ породжують багатозначність цього відносно нового в українському науковому дискурсі поняття (Табл. 2). 
Таблиця 2

Дефініції креативних індустрій

\begin{tabular}{|c|c|}
\hline Десрініція & Джерело \\
\hline $\begin{array}{l}\text { Креативні індустрії - діяльність, що спирається на особисту } \\
\text { креативність, майстерність і талант, та мають потенціал до створення } \\
\text { багатства і робочих місць шляхом продукування та використання } \\
\text { інтелектуальної власності }\end{array}$ & \begin{tabular}{lr} 
Британський & \multicolumn{2}{l}{ Департамент } \\
Культури, 3MI & та Спорту \\
(DCMS) [8; 9-32] &
\end{tabular} \\
\hline $\begin{array}{l}\text { Креативні індустрії - індустрії, метою яких є створення, виробництво і } \\
\text { комерціалізація творчих (креативних) змістів, які є нематеріальними } \\
\text { і культурними за своєю природою. Такі змісти зазвичай захищені } \\
\text { правом інтелектуальної власності і вони можуть набувати форму } \\
\text { продукту чи послуги }\end{array}$ & ЮНЕСКО [9] \\
\hline $\begin{array}{l}\text { Креативні індустрії - перелік видів економічної діяльності, що мають } \\
\text { потенціал до створення доданої вартості та робочих місць через } \\
\text { культурне (мистецьке) та/або креативне вираження, а їх продукти та } \\
\text { послуги є наслідком індивідуальної творчості, навичок і таланту. }\end{array}$ & Верховна Рада України [10] \\
\hline $\begin{array}{l}\text { Креативні індустрії - діяльність, що спирається на особисту } \\
\text { креативність, майстерність і талант, та має потенціал до створення } \\
\text { багатства і робочих місць шляхом продукування та використання } \\
\text { інтелектуальної власності; } \\
\text { Культурні індустрії - 1. галузь виробництва; 2. виробництво товарів, } \\
\text { як особливої форми виробництва культурних продуктів; 3. сектор } \\
\text { творчих (креативних) індустрій, який продукує та розповсюджує товари } \\
\text { та послуги в сфері культури (література, книговидання, видовищні } \\
\text { мистецтва, музика та ін.); 4. галузь національного господарства та } \\
\text { частина сфери культури, в межах якої відбувається масове } \\
\text { виробництво, розподіл та перерозподіл культурних благ шляхом } \\
\text { відтворення та тиражування унікальних мистецьких творів, прототипів } \\
\text { та інформаційного змісту за допомогою техніки та технологій; 5. галузь } \\
\text { національного господарства та частина сфери культури, в межах якої } \\
\text { відбувається масове виробництво, розподіл та споживання об'єктів } \\
\text { авторського права за допомогою техніки та технологій, створених } 3 \\
\text { метою задоволення естетичнихпотреб }\end{array}$ & $\begin{array}{l}\text { Український центр культурних } \\
\text { досліджень [11] }\end{array}$ \\
\hline $\begin{array}{l}\text { Культурні індустрії - явище постіндустріального суспільства, яке } \\
\text { виникає внаслідок пошуку нових смислів, форм смислоутворення і } \\
\text { професійної самореалізації і є фактором формування людського } \\
\text { капіталу; } \\
\text { Культурні індустрії - види діяльності, орієнтовані на надання } \\
\text { додаткових функцій сфері послуг, яка не просто займає частину } \\
\text { позаробочого часу, але й забезпечує задоволення культурних, } \\
\text { комунікативних і естетичних потреб людини }\end{array}$ & Є. Богатирьова [12] \\
\hline $\begin{array}{l}\text { Культурні індустрії- технології, базовим призначенням яких є масове } \\
\text { виробництво/поширення текстів, які несуть соціальні } \\
\text { (смисли, коди поведінки, стилі життя і т.п.) }\end{array}$ & А. Васнецький, С. Зуєв [13] \\
\hline
\end{tabular}

Джерело: сформовано автором на підставі [8-13]

Поняття «культурна індустрія» набуло поширення в середині XX ст. завдяки праці «Діалектика освіти» [14] Теодора Адорно і Макса Горкгаймера - представників Франкфуртської школи соціології. Робота побачила світ у 1947 році і містила дослідженні масової культури як продукту індустріального і постіндустріального суспільства. Ïї розділ «Індустрія культури: Просвіта як масовий обман» демонструє те, що, фрілософи досить критично поставились до стандартизації та масовості культурного продукту, зумовлених технічною раціональністю та масовою комунікацією.

Концепція креативних індустрій є відносно новою у західноєвропейському гуманітарному дискурсі, оскільки сформувалась в 70-ті рр. минулого століття. Саме в цей період на Заході склалися технологічні та інформаційно-комунікативні передумови формування креативних індустрій: індустріалізація, урбанізація, скорочення традиційних та поява нових фрорм зайнятості на ринку праці. Підґрунтя концепції креативних індустрій склали ідеї переоцінки впливу культури на розвиток суспільства, які у підсумку породили відмінні концептуальні напрямки дослідження. 
Першочергово до аналізу суспільного потенціалу креативних індустрій звернулись фрілософии і соціологи, однак реальні шляхи пошуку трансформації суспільства засобами культури обґрунтували економісти. Зокрема, в працях Т. Адорно, 3. Баумана, Д. Белла та ін. мислителівпостмодерністів креативні індустрії розглядались як тип соціально-культурних практик, що сформувались внаслідок становлення постіндустріального суспільства. Натомість фундатори концепції «креативної економіки» Дж. Хокінс, П. Луїджі Сакко та ін. акцентували увагу на креативних індустріях як секторі економіки, що створює додаткову вартість і робочі місця шляхом виробництва і експлуатації інтелектуальної власності. 3 позицій економічного підходу аналіз креативних індустрій нині здійснюють такі сучасні вітчизняні науковці, як С. Киризюк, Х. Лошковська, М. Проскуріна, А. Холодницька, О. Чуль та ін.

Тему культуротворчого потенціалу креативних індустрій розробляють такі сучасні вітчизняні вчені, як І. Петрова, С. Олійник, В. Солодовник, а також російські науковці Є. Богатирьова, $€$ Є Зєлєнцова, О. Лазарєва та ін. Попри зростаючий інтерес вчених та появу значної кількості зарубіжних і вітчизняних міждисциплінарних досліджень, роль креативних індустрій в процесі трансформації українського суспільства малодосліджена.

Разом з тим аналіз змістовного навантаження терміну «креативні індустрії» та особливостей його інтерпретації зарубіжною і вітчизняною науковою думкою, дозволяє констатувати, що спільною у вищезгаданих дослідженнях стає проблематика взаємодії культури і економіки на сучасному етапі суспільної трансформації. Визнається, що театр, образотворче мистецтво, кінематограф, телебачення, радіо, музика, видавнича справа, комп'ютерні ігри та інші індустрії, які походять з індивідуальної креативності, таланту мають потенціал для розвитку економіки і суспільства в цілому.

Загалом, аналіз концептуальної репрезентації креативних індустрій дозволяє виокремити основні підходи до визначення їх сутності (Табл. 3).

Концептуальні ідходи до тлумачення креативних індустрій

\begin{tabular}{|c|c|c|}
\hline Пiдxid & Характерні риси & Фундатори \\
\hline Культурологічний & $\begin{array}{l}\text { Культурні (креативні) індустрії розглядаються як форма та } \\
\text { інструмент масової культури, наділені її основними якостями - } \\
\text { здатністю пригнічувати та уніфікувати індивіда; фрактор } \\
\text { формування людського капіталу }\end{array}$ & $\begin{array}{l}\text { М. Горкхаймер, } \\
\text { Т. Адорно, } \\
€ \text { Є. Богатирьова } \\
\text { та ін. }\end{array}$ \\
\hline $\begin{array}{l}\text { Культурно- } \\
\text { економічний }\end{array}$ & $\begin{array}{l}\text { Креативні індустрії - це сукупність галузей економіки, що } \\
\text { характеризується органічним поєднанням і використанням } \\
\text { знань, інформації та творчості (креативності) }\end{array}$ & $\begin{array}{l}\text { У. Баумоль , } \\
\text { У. Боуен, } \\
\text { Дж. Хокінс та ін. } \\
\end{array}$ \\
\hline Мережевий & $\begin{array}{l}\text { Креативні індустрії - мережеві структури, що є організаціями, } \\
\text { які акумулюють творчий і креативний потенціал та культурний } \\
\text { потенціал для створення комерційно успішного продукту }\end{array}$ & $\begin{array}{l}\text { Б. Латура, } \\
\text { Дж. Сибрук }\end{array}$ \\
\hline $\begin{array}{l}\text { Знаково- } \\
\text { семіотичний }\end{array}$ & $\begin{array}{l}\text { Трактує креативні індустрії як види виробництва і поширення } \\
\text { продуктів, а саме текстів, які впливають на розуміння світу }\end{array}$ & $\begin{array}{l}\text { Д. Хезмондалш, } \\
\text { А. Васнецький, } \\
\text { С. Зуєв }\end{array}$ \\
\hline $\begin{array}{l}\text { Соціально- } \\
\text { культурний }\end{array}$ & $\begin{array}{l}\text { Вивчає креативні індустрії як тип соціально-культурних практик } \\
\text { постіндустріального суспільства }\end{array}$ & $\begin{array}{l}\text { 3. Бауман, } \\
\text { Д. Бел, У. Бек }\end{array}$ \\
\hline
\end{tabular}

Джерело: сформовано автором на підставі [3; 4; 12]

Множинність підходів до визначення сутності креативних індустрій (культурологічний, культурно-економічний, мережевий, знаково-семіотичний, соціально-культурний) дає підстави вважати креативні індустрії феноменом поліморфним та функціонально багатовимірним. З'ясування їх теоретико-методологічного потенціалу може слугувати темою подальших досліджень.

Висновки. Ефективне управління культурними проектами та розвиток культурних i креативних індустрій в сучасних умовах неможливі без урахування основних західноєвропейських та вітчизняних підходів до усвідомлення природи культури та особливостей їх трансформації на сучасному етапі суспільних перетворень. 
Для дослідження потенціалу культури в умовах глобалізації та складних процесів національного культуротворення в українському суспільстві, слід звернутися до аналізу концепту «культура» та виокремити основні підходи до його тлумачення.

Поняття культура (від лат. culture - «обробіток») багатозначне і набуває різних смислових відтінків в залежності від підходу, в контексті якого вживається. Аналіз численних пояснювальних схем та світоглядно-методологічних уявлень, представлених у зарубіжній та вітчизняній гуманітарній думці, дозволяє виокремити декілька основних підходів до усвідомлення природи культури: аксіологічний, діяльнісний, знаково-семантичний, психологічний, ігровий, матеріалістичний, стихійно-повсякденний і фрілософський.

Ураховуючи множинність вищезазначених підходів до усвідомлення природи культури у зарубіжній думці, звернемо увагу на його тлумачення в українській світоглядній традиції. Давньоукраїнським аналогом латинського поняття «культура» було слово «художества». Це означає, що культурою українські мислителі називали дещо створене, відмінне від оригіналу, дійсності.

Множинність підходів до визначення сутності креативних індустрій (культурологічний, культурно-економічний, мережевий, знаково-семіотичний, соціально-фрілософрський) дає підстави вважати креативні індустрії феноменом поліморфнним та функціонально багатовимірним.

Разом з тим аналіз змістовного навантаження терміну «креативні індустрії» та особливостей його інтерпретації зарубіжною і вітчизняною науковою думкою, дозволяє констатувати, що спільною у вищезгаданих дослідженнях стає проблематика взаємодії культури і економіки на сучасному етапі суспільної трансформації.

На нашу думку, значний теоретико-методологічний потенціал у справі концептуалізації культури та культурних (креативних) індустрій має філософсько-антропологічний підхід, який властивий українській світоглядній традиції і розглядає культуру як поле духовної самореалізації особистості, здійснення індивідуальних свобод людини та основу соціальної інтеграції і самоорганізації.

\section{Література}

1. Губерський, Л. В. Культура. Ідеологія. Особистість: Методолого-світоглядний аналіз. / Л. В. Губерський, В. П. Андрущенко, М. І. Михальченко. - К. : Знання України, 2002. - 580 с.

2. Білоус, А. Соціокультурні чинники громадянського суспільства: Центральна Європа та Україна / А. Білоус, Я. Пасько // Схід. - 2009. - № 8 (99). - С. 125-129.

3. Хрестоматия по культурологии. Самосознание русской культуры / под ред. И. Ф. Кефели, В. Т. Пуляева, В. П. Сальникова, С. В. Степашина. - Санкт-Петербург, 2000. - Том 2. - 512 с.

4. Гейзінга, Й. Homo Ludens / Й. Гейзінга ; пер. з англ. О. Мокровольського. - К. : Основи, 1994. - 250 с.

5. Шевченко, В. Дружба з мудрістю або ключові проблеми української філософрії (Теоретико-методологічний коментар до курсу філософії у ВН3) / В. Шевченко. - К. : Фоліант, 2007. - 244 с.

6. Великий тлумачний словник української мови / упоряд. Т. В. Ковальова. - Х. : Фоліо, 2005. - 767 с.

7. Давимука, С. А. Креативний сектор економіки: досвід та напрями розбудови: монограсрія / С. А. Давимука, Л. І. Федулова; ДУ «Інститут регіональних досліджень імені М. І. Долішнього НАН України». - Львів, 2017. -528 c.

8. Flew T., 2012 b. Origins of creative industries policy. In: Flew T. (ed.), The creative industries: Culture and policy. SAGE Publications Ltd, Los Angeles: 9-32.

9. Офріційна сторінка ЮНЕСКО - URL: http://portal.unesco.org/culture.

10. «Про внесення змін до Закону України «Про культуру» щодо визначення поняття «креативні індустрії». Закон України. - URL: http://zakon.rada.gov.ua/laws/show/2458-viii.

11. Глосарій креативних індустрій. - URL: http://uccs.org.ua/hlosarij-kreatyvnykh-industrij.

12. Богатырёва, Е. А. Фактор времени в становлении культурных индустрий / Е. А. Богатырёва // Культурологический журнал - 2012. № 1 (7). - URL: http://www.cr-journal.ru/rus/journals/118.html\&j_id=9.

13. Васнецкий, А. А. Культурные индустрии как значимый фрактор политики [Электронный ресурс] / А. А. Васецкий, С. Э. Зуев // Власть. - 2010. - N 4. - С. 65-69. - URL: http://cyberleninka.ru/article/n/kulturnye-industrii-kakznachimyy-faktorpolitiki.

14. Хоркхаймер, М. Диалектика просвещения. Философские фрагменты : пер. с нем. / Макс Хоркхаймер, Теодор Адорно - М., СПб. : Медиум, Ювента, 1997. -312 с.

\section{References}

1. Huberskyi, L., Andrushchenko, V. P., Mykhalchenko, M. I. (2009). Filosofiia yak teoriia ta metodolohiia rozvytku osvity [Culture. Ideology. Personality: Methodological and ideological analysis]. Kyiv: [in Ukrainian].

2. Bilous, A., Pasko, Y. (2009). Sotsioculturnii chynnyky hromadianskoho suspilstva: Sentralna Yevropa [Socio-cultural factors of civil society: Central Europe]. Shid - East, 8(99), 125-129 [in Ukrainian]. 
3. Kefeli, I. F., Pulyaeva, V. T., Salnikova, V. P., Stepashina, S. V. (Eds.). Hrestomatia po kulturolohii. Samosoznanie russkoi kultury [Textbook of culturology. Self-awareness of Russian culture]. (Vols. 2). Saint Petersburg [in Russian].

4. Heizinha, I. (1994). Homo Ludens [Homo Ludens]. Kyiv: [in Ukrainian].

5. Shevchenko, V. I. (2007). Druzhba z mudristiu abo kliuchovi problemy ukrainskoi filosofii (Teoretyko-metodolohichnyi komentar do kursu filosofii u VNZ) [Friendship with wisdom or key problems of Ukrainian philosophy (Theoretical and methodological commentary on the course of philosophy in universities]. Kyiv: Foliant [in Ukrainian].

6. Kovalova, T. V. (2005). Velykyi tlumachnyi slovnyk ukrainskoi movy [Large explanatory dictionary of the Ukrainian language]. Kharkiv: Folio [in Ukrainian].

7. Davymuka, S. A., Fedulova, L. I. (2017). Creatyvnyi sektor ekonomiky: dosvid ta napriamy rozbudovy [Creative sector of economy: experience and directions of development]. Lviv: DU «Instytut rehionalnykh doslidzhen imeni M. I. Dolishnoho NAN Ukrainy» [in Ukrainian].

8. Flew T., (2012). Origins of creative industries policy. The creative industries: Culture and policy. (pp. 9-32). Los Angeles: SAGE Publications Ltd [in English].

9. Official site of UNESCO. unesco.org. Retrieved from http://portal.unesco.org/culture [in English].

10. Zakon Ukrainy "Pro vnesennia zmin do Zakonu Ukrainy "Pro kulturu" shchodo vyznachennia poniattia "kreatyvni industrii" : vid 19 chervnia 2018 roku, № 2458-VIII [Law of Ukraine "On Amendments to the Law of Ukraine" On Culture "to Define the Concept of" Creative Industries" from June 19, 2018 № 2458-VIII]. zakon.rada.gov.ua. Retrieved from http://zakon.rada.gov.ua/laws/show/2458-viii [in Ukrainian].

11. Hlosaryi creativnykh industryi [Glossary of creative industries]. (n.d.). uccs.org.ua. Retrieved from http://uccs.org.ua /hlosarij-kreatyvnykh-industrij [in Ukrainian].

12. Bogatyreva, E. A. (2012). Faktor vremeni v stanovlenii kulturnykh industriy [The time factor in the formation of cultural industries]. Kulturologicheskiy zhurnal - Cultural Journal, 1(7). Retrieved from http://www.crjournal.ru/rus/journals/118.html\&__id=9/[in Russian].

13. Vasniyetskyi, A.A., Zuyev, S.E. (n.d.). Kulturnie industriy kak znachimyi factor politiki [Cultural industries as a significant factor in politics]. cyberleninka.ru. Retrieved from http://cyberleninka.ru/article/n/kulturnye-industrii-kak-znachimyyfaktorpolitiki [in Russian].

14. Horkheimer, M., Adorno, T. W. (1997). Dialektika prosveshcheniya. Filosofskie fragmenty [Dialectic of Enlightenment]. (M. Kuznetsov, Trans). Moscow; Saint Petersburg: Medium Yuventa [in Russian].

Надійшла 30.10.2019

Бібліографрічний опис для цитування:

Шакун, Н.В. До питання концептуалізації поняття культурних і креативних індустрії / Н. В. Шакун // Проблеми соціальної роботи: філософія, психологія, соціологія. - 2019. - № 2 (14). - С. 91-99. 